\title{
Species and functional diversity of ectomycorrhizal fungal communities on Scots pine (Pinus sylvestris L.) trees on three different sites
}

\author{
Maria Rudawska • Tomasz Leski • \\ Małgorzata Stasińska
}

Received: 7 March 2010 / Accepted: 21 September 2010/Published online: 19 January 2011

(C) The Author(s) 2011. This article is published with open access at Springerlink.com

\begin{abstract}
- Introduction In the present study, we describe the aboveground (epigeous sporocarps) and belowground (ectomycorrhizal root tips and their exploration types) composition of ectomycorrhizal (ECM) fungal species on three 20-year-old Scots pine sites.

- Objectives The aim of this study was to relate the composition of ECM species to history of the site, stand density and soil chemistry ( $\mathrm{pH}$, toxic metal content, etc.) and to show how variable site condition contribute to above- and belowground ECM community changes.

- Results ECM fungi were identified by combination of morphotyping and direct sequencing of the PCR-amplified internal-transcribed spacer of n-rDNA. By identifying sporocarps and mycorrhizas, we detected a total of 54 taxa of ECM fungi: 28, 30, and 23 species at the Kórnik (control), Luboń (near the chemical plant) and Głogów (near the Copper Smelter, heavy metal influenced) sites, respectively. The sporocarp survey weakly reflected the analysis of ECM tips in terms of species composition, and largely supplemented the belowground view. Wilcoxina rehmii was the belowgrounddominating species at all three sites and was found at the highest abundance at the site established after the clear cut of poplars and with the highest tree density (Kórnik). At the
\end{abstract}

Handling Editor: Jean Garbaye

M. Rudawska $(\bowtie) \cdot$ T. Leski

Laboratory of Mycorrhizal Research,

Institute of Dendrology Polish Academy of Sciences,

Parkowa 5,

62-035 Kórnik, Poland

e-mail: mariarud@man.poznan.pl

M. Stasińska

Department of Botany, University of Szczecin,

Felczaka 3a,

PL-71-412 Szczecin, Poland
Luboń site, subdominant mycorrhizas were formed by Phialophora finlandia. On the site near the Copper Smelter in Głogów, a significant shift in species composition was observed compared with the two other sites and a very large proportion of medium-fringe exploration type belonging to Atheliaceae was found. Despite the partial overlap in the nonmetric multi-dimensional scaling ordination, analysis of similarity revealed significant differences between tested sites. - Conclusion Because of the number of covarying site properties which may influence ECM communities, it is difficult, if not unfeasible, to separate the precise reasons of the distribution of ECM fungi. Continued research on the biodiversity of ECM fungi in field sites along an environmental gradient would greatly improve our understanding of the effects of ecological conditions on the functional diversity of mycorrhizal fungi.

Keywords Sporocarps · Mycorrhiza - Exploration types · Atheliaceae $\cdot$ Heavy metals

\section{Introduction}

The root systems of most forest trees in temperate and boreal forest soils form mutualistic symbiotic relationships with various ectomycorrhizal (ECM) fungi. ECM fungi are essential to tree nutrition; they exchange nutrients taken up from the soil and provide protection from root diseases, and also confer tolerance to different stress factors, including trace metals (Smith and Read 1997). Consequently, the colonization rate and species composition of ECM fungi may influence plant fitness and the development of plant community structure, and therefore the stability of forest ecosystems (Haselwandter and Bowen 1996), especially on disturbed soils (Grossnickle and Reid 1983). Ectomycorrhizal fungal communities are highly diverse. Tree roots are 
exposed to several hundred different species of ectomycorrhizal fungi often with 20-50 species within a few hundred square meters (e.g., Dahlberg et al. 1997; Jonsson et al. 2000). ECM root species richness and/or community structure are influenced by a range of biotic and abiotic factors, including forest composition and chronosequences, host genotype, host specificity, soil type, soil moisture, season, natural nutrient gradients, activities of herbivores and plant parasites and the quality and quantity of organic matter. ECM fungal communities can also be strongly influenced by a range of forest management practices and by gradients of nitrogen deposition. Further, anthropogenic factors that have been shown to influence ECM root communities include nitrogen addition, acid precipitation, elevated atmospheric $\mathrm{CO}_{2}$ concentrations, toxic metal contamination, and other forms of anthropogenic pollution. Most factors mentioned above were thoroughly described and discussed in several review papers (Cairney and Meharg 1999; Erland and Taylor 2002; Finlay et al. 2008; Jones et al. 2003; Kernaghan 2005; Simard 2009).

Although the effects of individual biotic and abiotic factors on ECM communities have been fairly well characterized, the functional role of ECM fungal diversity is largely unexplored. Studies of how the symbiotic association functions under controlled conditions suggest specialization and complementarity of the different ECM types for functions beneficial to the trees: water uptake, mobilization and assimilation of nutrients, growth regulation, and protection against pathogenic organisms or toxic metals (Dahlberg 2001; Smith and Read 1997). Scots pine (Pinus sylvestris L.), a widely distributed tree species that is well adapted to growth in the podzolic boreal soils, is a known host for 200-300 mycorrhizal fungal species based on aboveground sporocarp surveys (Hintikka 1988). However, these diverse macrofungal communities vary markedly in composition from site-to-site. Since the early 1990s, studies about the ecology and function of ECM fungi have entered a new period with the use of molecular techniques utilizing DNA (Horton and Bruns 2001). An important step forward in describing the functional diversity of ECM fungi was establishing different exploration types of ectomycorrhizas, as proposed by Agerer (2001), based on the amount of emanating hyphae and the presence and differentiation of rhizomorphs. Agerer (2001) suggested that the exploration types of ECM mycelia might mirror their ecological function.

Because little is known about the functional role of the ectomycorrhizal community in young Scots pine monocultures, the primary aim of this study was to relate the aboveground (epigeous sporocarps) and belowground (ECM root tips and their exploration types) composition of ECM species to history of the site, stand density and soil chemistry ( $\mathrm{pH}$, toxic metal content, etc.) at three different sites. We expected that some ECM fungi would be associated with Scots pine across all three sites but that variable site condition would contribute to above- and belowground ECM community changes.

\section{Materials and methods}

\subsection{Study sites}

The research was performed at three study sites (Kórnik, Luboń, and Głógów) established in west-central Poland, as a part of the IUFRO provenance experiment. Each site was afforested in 1984 with Scots pine seedlings from 20 European provenances. The experiment set-up is detailed in Oleksyn (1988).

The first site was located near Kórnik in the "Zwierzyniec" Experimental Forest. The site was previously covered by poplars, which were removed during winter 1983/1984. Apart from the planted Scots pine trees, self-sown spruce trees and elder bushes grow in the area (spruces mainly at the northern border). This site belongs to an area free of acute air pollution and was considered as a control site.

The second site was located in Lubon $2 \mathrm{~km}$ on the east direction from the Chemical Plant Luboń Ltd. (formerly Phosphate Fertilizer Plant), on wasteland, postagricultural land. Preceding the provenance experiment, the site was covered by scattered Scots pine trees. The Luboń site has been exposed to air pollution emitted by nearby industrial works since 1914. Annual emission rates were declined lately: $\mathrm{SO}_{2}$ from 2,608 $t$ in 1980 to $5 \mathrm{t}$ in 1998, NOx from $63 \mathrm{t}$ in 1990 to $4 \mathrm{t}$ in 2004 and fluorine compounds from $169 \mathrm{t}$ in 1982 to $1.5 \mathrm{t}$ in 2004. In recent years, substantial reduction in pollutant emissions had associated with the elimination of sulphuric acid production by the nitrose method (which took place in 1982 too), termination of the acid production by the contact method in 1990, and a reduction in the use of granulated superphosphate (Karolewski and Giertych 1995). This site was regarded as slightly polluted site.

The third research site was situated within the buffer zone B of the Copper Smelter in Głogów, $2.5 \mathrm{~km}$ in north-east direction from the smelter and was considered as heavy metal-influenced site. The Głogów Copper Smelter is part of a mining and metallurgy complex founded in 1959, which currently includes four mines, three ore enrichment plants (with two tailings ponds), and three smelters. The Głogów site was situated on postagricultural land and became part of the buffer zone of the Copper Smelter in 1981-1982. Since the 1970s, this site has been subjected to pollution with large amounts of heavy metal-containing dusts (e.g., $\mathrm{Cu}, \mathrm{Pb}$, $\mathrm{Zn}, \mathrm{Cd}$ ) and sulfur dioxide, released by the smelter (Oleksyn 1988). In 1980, it emitted 14,442 $t$ of dusts and $125,700 \mathrm{t}$ of $\mathrm{SO}_{2}$ per year. The pollution was gradually 
Table 1 Site characteristics and soil chemical properties at the three study sites
${ }^{\mathrm{a}}$ Letters indicate significant differences between sites at $p<0.05$ (Tukey's test)

\begin{tabular}{|c|c|c|c|}
\hline & \multicolumn{3}{|l|}{ Study site } \\
\hline & Kórnik & Luboń & Głogów \\
\hline Localization & $52^{\circ} 15^{\prime} \mathrm{N}, 17^{\circ} 04^{\prime} \mathrm{E}$ & $52^{\circ} 19^{\prime} \mathrm{N}, 16^{\circ} 55^{\prime} \mathrm{E}$ & $51^{\circ} 41^{\prime} \mathrm{N}, 16^{\circ} 01, \mathrm{E}$ \\
\hline Soil type & Eutric cambisols & Podsols & Podsols \\
\hline Area size (ha) & 0.51 & 0.3 & 0.43 \\
\hline Spacing of trees $(\mathrm{m})$ & $1.5 \times 0.5$ & $1.5 \times 0.75$ & $1.5 \times 0.75$ \\
\hline Mean annual temperature (2000-2002) & 9.7 & 9.7 & 9.8 \\
\hline Mean annual precipitation (2000-2002) & 581 & 581 & 672 \\
\hline $\mathrm{pH}_{\mathrm{H} 2 \mathrm{O}}$ & $6.7 \mathrm{a}^{\mathrm{a}}$ & $4.5 \mathrm{~b}$ & $6.6 \mathrm{a}$ \\
\hline $\mathrm{pH}_{\mathrm{KCl}}$ & $5.6 \mathrm{a}$ & $3.7 \mathrm{~b}$ & $5.9 \mathrm{a}$ \\
\hline $\mathrm{N}-\mathrm{NH}_{4}\left(\mathrm{mg} \mathrm{g}^{-1}\right)$ & $0.93 \mathrm{~b}$ & $0.92 \mathrm{~b}$ & $1.51 \mathrm{a}$ \\
\hline $\mathrm{N}-\mathrm{NO}_{3}\left(\mathrm{mg} \mathrm{g}^{-1}\right)$ & $0.22 \mathrm{a}$ & $0.16 \mathrm{~b}$ & $0.14 \mathrm{~b}$ \\
\hline $\mathrm{P}\left(\mathrm{mg} \mathrm{kg}^{-1}\right)$ & $4.6 \mathrm{a}$ & $1.2 \mathrm{~b}$ & $1.5 \mathrm{~b}$ \\
\hline $\mathrm{K}\left(\mathrm{mg} \mathrm{kg}^{-1}\right)$ & $39.2 \mathrm{a}$ & $13.5 \mathrm{~b}$ & $42.4 \mathrm{a}$ \\
\hline $\mathrm{Ca}\left(\mathrm{mg} \mathrm{kg}^{-1}\right)$ & $273 \mathrm{a}$ & $25.2 \mathrm{~b}$ & $287 \mathrm{a}$ \\
\hline $\operatorname{Mg}\left(\mathrm{mg} \mathrm{kg}^{-1}\right)$ & $21.5 \mathrm{a}$ & $5.7 \mathrm{~b}$ & $20.8 \mathrm{a}$ \\
\hline $\mathrm{Cu}$-total $\left(\mathrm{mg} \mathrm{kg}^{-1}\right)$ & $6.9 \mathrm{~b}$ & $1.9 \mathrm{c}$ & $267.1 \mathrm{a}$ \\
\hline $\mathrm{Cu}-$ EDTA $\left(\mathrm{mg} \mathrm{kg}^{-1}\right)$ & $4.6 \mathrm{~b}$ & $1.2 \mathrm{~b}$ & $156.2 \mathrm{a}$ \\
\hline $\mathrm{Pb}$-total $\left(\mathrm{mg} \mathrm{kg}^{-1}\right)$ & $7.9 \mathrm{~b}$ & $5.8 \mathrm{~b}$ & $81.4 \mathrm{a}$ \\
\hline $\mathrm{Pb}-\mathrm{EDTA}\left(\mathrm{mg} \mathrm{kg}^{-1}\right)$ & $5.3 \mathrm{~b}$ & $3.7 \mathrm{~b}$ & $49.1 \mathrm{a}$ \\
\hline $\mathrm{Zn}$-total $\left(\mathrm{mg} \mathrm{kg}^{-1}\right)$ & $6.3 \mathrm{~b}$ & $1.6 \mathrm{c}$ & $29.8 \mathrm{a}$ \\
\hline $\mathrm{Zn}-\mathrm{EDTA}\left(\mathrm{mg} \mathrm{kg}^{-1}\right)$ & $4.0 \mathrm{~b}$ & $1.0 \mathrm{c}$ & $18.5 \mathrm{a}$ \\
\hline Cd-total $\left(\mathrm{mg} \mathrm{kg}^{-1}\right)$ & $0.11 \mathrm{~b}$ & $0.10 \mathrm{~b}$ & $0.45 \mathrm{a}$ \\
\hline Cd-EDTA $\left(\mathrm{mg} \mathrm{kg}^{-1}\right)$ & $0.07 \mathrm{~b}$ & $0.07 \mathrm{~b}$ & $0.29 \mathrm{a}$ \\
\hline $\mathrm{Al}\left(\mathrm{mg} \mathrm{kg}^{-1}\right)$ & $43.2 \mathrm{~b}$ & $87.7 \mathrm{a}$ & $52.3 \mathrm{a}$ \\
\hline $\operatorname{Mn}\left(\mathrm{mg} \mathrm{kg}^{-1}\right)$ & $29.2 \mathrm{a}$ & $6.8 \mathrm{~b}$ & $3.3 \mathrm{c}$ \\
\hline $\mathrm{Fe}\left(\mathrm{mg} \mathrm{kg}^{-1}\right)$ & $71.3 \mathrm{a}$ & $49.6 \mathrm{~b}$ & $89.5 \mathrm{a}$ \\
\hline
\end{tabular}

reduced to 2,017 t of dust and 34,100 $\mathrm{t}$ of $\mathrm{SO}_{2}$ in 1990 and then $179 \mathrm{t}$ of dust and 4,000 $\mathrm{t}$ of $\mathrm{SO}_{2}$ in 2005 (http://www. kghm.pl/). More details about study sites and stand characteristics are listed in Table 1.

\subsection{Chemical analysis of the soil}

The chemical analysis was performed using the Elemental Combustion System 4010 and atomic absorption spectroscopy (Varian 220 FS). Total and bioavailable heavy metal concentrations were estimated in separate extraction (with concentrated, $72 \% \mathrm{HClO}_{4}$ and $0.1 \mathrm{M}$ EDTA, respectively). The accuracy of the analyses was checked against standard reference materials: standard Chinese soils NCS DC 73322, NSC DC 73322, DX STII\#57590, and DX \#46070. Assays were carried out at the Laboratory of Environmental Ecology, Institute of Botany, Kraków, Poland. The $\mathrm{pH}$ of soil samples was determined by mixing $20 \mathrm{ml}$ of soil substrate with $40 \mathrm{ml}$ of deionized water and $0.5 \mathrm{M} \mathrm{KCl}$, respectively. After $1 \mathrm{~h}$, the $\mathrm{pH}$ was measured with a calibrated $\mathrm{pH}$ meter equipped with a glass electrode.

\subsection{Survey of sporocarps}

Sporocarps of epigeous ECM macromycetous species were surveyed during the growing season in 2000, 2001, and 2002. Field surveys were conducted every 4-6 weeks between May and November. Fruiting bodies were identified and counted on all plots. Herbarium specimens are deposited in the Laboratory of Mycorrhizal Research, Institute of Dendrology, Kórnik.

\subsection{Sampling and identification of mycorrhizas}

For mycorrhizal analysis, $P$. sylvestris trees belonging to provenance No 5 from Miłomłyn in Poland were chosen. The soil samples were collected in October 2000, 2001, and 2002 with a soil sampler (diameter $=5 \mathrm{~cm}$ ) from the organic and mineral layer, to a depth of $5 \mathrm{~cm}$. In each year, 12 soil cores were collected at about $80 \mathrm{~cm}$ distance from the tree trunk (three samples per tree) on each of the three study sites, yielding a total of 36 samples per site. Soil samples were kept in plastic bags and stored at $4^{\circ} \mathrm{C}$ until ready for processing, but not longer than 3 weeks. At that time, fine 
roots $(<2 \mathrm{~mm})$ were separated from soil and organic matter on a sieve under a stream of cold water. The final separation and counting of roots were conducted under the stereomicroscope.

Mycorrhizas were classified into morphotypes based on morphological characters according to Agerer (1987-2008). ECM morphotypes were also classified into exploration types given by Agerer (2001): "contact" types had smooth mantles and no rhizomorphs, "short distance" types had emanating hyphae with no rhizomorphs, "medium fringe distance" types had long emanating hyphae with diffuse rhizomorphs, "medium smooth distance" types had few or no emanating hyphae and undifferentiated rhizomorphs, and "long distance" types had smooth mantles and highly differentiated rhizomorphs.

The number of mycorrhizas of each morphotype was recorded separately for each sample. The number of mycorrhizas on each site was calculated per $1 \mathrm{~g}$ of root dry weight (in order to exclude an effect of tree spacing between study sites). For each morphotype, sample of five to ten fresh, thoroughly rinsed ECM tips were placed in Eppendorf tubes in cetyltrimethyl ammonium bromide buffer and stored at room temperature until processing for DNA analysis. We made no attempt to relate morphotypes between soil samples until molecular analysis was complete; thus, each morphotype sample was treated separately in a subsequent molecular typing and pooled for abundance calculation only after the molecular analysis indicated that morphotypes are identical. Mycorrhizal colonization ratio (number of mycorrhizas per total number of fine root tips) was ascertained. The relative abundance of ectomycorrhizal species were calculated separately for each soil sample as a proportion of ECM root tips of a given species to total number of mycorrhizas present in sample and then averaged over all samples from given study site.

\subsection{Molecular identification}

Ectomycorrhizal fungi were identified using sequencing of the PCR amplified internal transcribed spacer (ITS) of n-rDNA. DNA was extracted using the miniprep method developed by Gardes and Bruns (1996). DNA was amplified following the protocol of Henrion et al. (1994) as modified by Kåren et al. (1997) with ITS1F and ITS4 primers.

Complete methods for molecular identification of mycorrhizas are presented in our previous papers (Aučina et al. 2007; Leski et al. 2010). Multiple PCR products (double DNA bands on the gel) were discarded from the analysis. Sequences were considered as identified at the species level when more than $98 \%$ identity with reference sequences (if available, derived from fruiting body) was obtained.
Otherwise, sequences were aligned with closest matches and their associates and submitted to neighbor-joining analysis for taxonomic interpretation at the genus or family level.

\subsection{Statistical analysis}

Above- and belowground ECM diversity at each study site was assessed using Shannon-Wiener diversity index, Simpson's diversity index dominance, and evenness index. Species accumulation curves (Mao Tau) and estimators of true species richness (Jackknife1 and Chaol richness estimator) were calculated with EstimateS program version 8.0 using 100 randomized runs without sample replacement. Multivariate, belowground community analyses of mycorrhizal fungi were carried out with PAST 1.89 software, based on square root-transformed data. The data matrix consisted of 108 samples with relative abundance of each ECM fungal species within each sample. The BrayCurtis coefficient was used to produce a dissimilarity matrix of species composition between any two samples. To visualize differences (based on the Bray-Curtis matrix) in the mycorrhizal community structure, nonmetric multidimensional scaling ordination (NMDS) was used. Oneway analysis of similarity (ANOSIM) was performed to test differences in relative abundance of mycorrhizal fungal species among study sites. A canonical correspondence (CCA) was carried out using CANOCO (Version 4.5). For CCA, the data were $\log$ transformed $(\log 10+1)$. Scaling was focused on inter-species correlation. Centering and standardization was used for species data. The significance of the species-environment relationship was assessed using the implemented Monte Carlo permutation test (499 permutations under full model). Analysis of variance with Tukey's test was used to compare the soil parameters, relative abundance of exploration types and ecological indices between tested Scots pine sites.

\section{Results}

\subsection{Soils}

Soil properties of all sites are summarized in Table 1 . Soil from the Kórnik and Głogów sites was slightly acid $\left(\mathrm{pH}_{\mathrm{KCl}}=5.6\right.$ and 5.9, respectively), while the Lubon site was acid $\left(\mathrm{pH}_{\mathrm{KCl}}=3.7\right)$. The concentrations of macroelements and trace metals in the upper soil layer differed significantly among sites, mostly one (Głogów) being different from other two (Kórnik and Luboń). The highest level of heavy metals $(\mathrm{Cu}, \mathrm{Pb}, \mathrm{Zn}, \mathrm{Cd})$ was noted in the Głogów site, situated in the vicinity of a Copper Smelter where the concentrations of bioavailable $\mathrm{Cu}$ and $\mathrm{Pb}$ were ten- 
and twofold higher for $\mathrm{Cu}$ and $\mathrm{Pb}$, respectively, than the average total contents in soils of similar types (KabataPendias and Mukherjee 2007). The highest concentration of aluminum was observed at the Lubon site, situated close to the Chemical Plant.

\subsection{Sporocarps occurrence of macromycetes}

Sporocarps from 31 species of ectomycorrhizal Basidiomycetes belonging to the orders Agaricales, Boletales, Cortinariales, Russulales, Sclerodermales, and Thelephorales were found at the three study sites (Table 2). Seven mycorrhizal fungi within

Table 2 Productivity (total number of sporocarps) of epigeous ectomycorrhizal fungi at the three study sites in years 2000-2002

\begin{tabular}{|c|c|c|c|}
\hline \multirow[t]{2}{*}{ Species } & \multicolumn{3}{|c|}{ Study site } \\
\hline & Kórnik & Luboń & Głogów \\
\hline Amanita muscaria & & 264 & 55 \\
\hline C. piperatus & & 8 & \\
\hline C. cinnamomeus & & 33 & \\
\hline Cortinarius sp. 1 & 5 & & \\
\hline Cortinarius sp. 2 & 9 & & \\
\hline Cortinarius sp. 3 & 8 & & \\
\hline Cortinarius sp. 4 & 4 & & \\
\hline Hebeloma crustuliniforme & 30 & 32 & \\
\hline H. mesophaeum & 6 & & \\
\hline H. sinapizans & & 7 & \\
\hline Laccaria laccata & & 381 & 504 \\
\hline L. proxima & & 36 & \\
\hline L. tortilis & 88 & & \\
\hline Lactarius rufus & & 338 & 19 \\
\hline P. involutus & 3 & 404 & 315 \\
\hline R. roseolus & 3 & & \\
\hline R. fragilis & 5 & & \\
\hline R. ochroleuca & & 3 & \\
\hline Russula sp. & 5 & & \\
\hline S. bovista & 6 & & \\
\hline S. citrinum & 19 & 15 & 351 \\
\hline S. bovinus & & & 18 \\
\hline S. granulatus & & 3 & \\
\hline S. luteus & 19 & 637 & 59 \\
\hline Thelephora terrestris & & 42 & 17 \\
\hline Tricholoma sp. 1 & & 8 & \\
\hline Tricholoma sp. 2 & & 7 & \\
\hline T. terreum & & & 19 \\
\hline$X$. badius & 7 & & \\
\hline$X$. chrysenteron & 3 & & \\
\hline X. subtomentosus & 2 & 5 & 2 \\
\hline Total number of sporocarps & 222 & 2,223 & 1,359 \\
\hline
\end{tabular}

the genera Cortinarius, Russula, and Tricholoma remained unidentified at species level. Seventeen ectomycorrhizal fungal species were encountered at the control site in Kórnik. The same number of species was observed at the Lubon site, near the Chemical Plant. At the Głogów site, close to the Copper Smelter, ten ECM fungal species were found. Four ECM fungal species were shared among all three sites: Suillus luteus, Xerocomus subtomentosus, Scleroderma citrinum, and Paxillus involutus (Table 2). Xerocomus badius, Xerocomus chrysenteron, Scleroderma bovista, Rhizopogon roseolus, Hebeloma mesophaeum, Laccaria tortilis, Russula fragilis, Russula sp.1, and four species of Cortinarius were restricted to the Kórnik site. Laccaria proxima, Hebeloma sinapizans, Russula ochroleuca, Cortinarius cinnamomeus, Chalciporus piperatus, Suillus granulatus, and two species of Tricholoma were species specific to the Lubon site, while sporocarps of Suillus bovinus and Tricholoma terreum were found exclusively at the Głogów site. Total sporocarp production was the highest at the Lubon site and the lowest at the Kórnik (Table 2). The Shannon-Wiener and Simpson diversity indices were significantly lower at the site near the Copper Smelter (Głogów) than at Kórnik and Luboń. The species dominance index was highest at Głogów, while evenness was not influenced by site (Table 3).

\subsection{Belowground ECM community}

The examination of pine roots from all three sites revealed a mycorrhizal colonization degree of $100 \%$. The total number of mycorrhizas when calculated per gram of dry weight of roots did not differ between Kórnik and Luboń site but was significantly lower for the Scots pines growing at Głogów site (Table 3).

Direct sequencing of distinguished morphotypes revealed a total of 29 ECM fungal taxa on the roots of tested Scots pines. Taxa richness in Kórnik, Luboń, and Głogów were 13, 17, and 16, respectively. Mean taxa richness in soil core was significantly higher at the Lubon site (Table 3). Five ECM taxa were shared among all three sites (Wilcoxina rehmii, Phialophora finlandia, Pyrenomycetaceae, Cenococcum geophilum, and P. involutus). One morphotype was associated exclusively with pines in Kórnik, five were exclusive to Luboń, and 11 were exclusive to Głogów (Fig. 1). Species accumulation curves did not reach an asymptote for the Kórnik site, but leveled off for the Luboń and Głogów sites (Fig. 2). The Jackknife1 and Chaol richness estimators predicted respective values of 15.9 and 13.5 species for Kórnik, 17.5 and 17.2 species for Luboń, and 17 and 16.6 species for Głogów (Table 3).

The relative abundance and distribution of each ECM species observed at the screened sites is presented in Fig. 1. At all three sites, the dominant mycorrhizal symbiont was W. rehmii, which accounted for $76 \%$ of the pine mycorrhizas 
Table 3 Shannon-Wiener and Simpson diversity, evenness, and dominance indices of above- and belowground ectomycorrhizal communities and root dry weight, number of mycorrhizas, mean and estimated species richness of ectomycorrhizal fungal taxa associated with Scots pine trees from three study sites ferences between sites at $p<0.05$ (Tukey's test)

\begin{tabular}{llll}
\hline & Kórnik & Luboń & Głogów \\
\hline Aboveground & & & \\
Diversity & & & \\
Shannon-Wiener $H^{\prime}$ & $2.16 \mathrm{a}^{\mathrm{a}}$ & $1.91 \mathrm{a}$ & $1.56 \mathrm{~b}$ \\
Simpson 1/D & $5.05 \mathrm{a}$ & $5.47 \mathrm{a}$ & $3.81 \mathrm{~b}$ \\
Dominance & $0.19 \mathrm{a}$ & $0.18 \mathrm{a}$ & $0.26 \mathrm{~b}$ \\
Evenness & $0.76 \mathrm{a}$ & $0.66 \mathrm{a}$ & $0.67 \mathrm{a}$ \\
Belowground & & & $122 \pm 67 \mathrm{~b}$ \\
Root d. w./100 cm ${ }^{3}$ of soil (mg) & $139 \pm 32 \mathrm{~b}$ & $258 \pm 36 \mathrm{a}$ & $1083 \pm 625 \mathrm{~b}$ \\
No of mycorrhizas/g root d. w. & $3798 \pm 458 \mathrm{a}$ & $3349 \pm 394 \mathrm{a}$ & $3.74 \mathrm{~b}$ \\
Mean no of taxa per core & $4.13 \mathrm{~b}$ & $6.72 \mathrm{a}$ & 16 \\
Found taxa richnes & 13 & 17 & 16.97 \\
Estimated species richness & & & 16.55 \\
Jackknife1 & 15.92 & 17.54 & \\
Chao1 & 13.5 & 17.25 & $0.77 \mathrm{~b}$ \\
Diversity & & & $2.16 \mathrm{~b}$ \\
Shannon-Wiener $\left(H^{\prime}\right)$ & $0.93 \mathrm{~b}$ & $3.25 \mathrm{a}$ & $0.60 \mathrm{a}$ \\
Simpson 1/D & $2.21 \mathrm{~b}$ & $0.34 \mathrm{~b}$ & $0.73 \mathrm{a}$ \\
Dominance & $0.48 \mathrm{~b}$ & $0.69 \mathrm{a}$ &
\end{tabular}

in Kórnik, 41\% in Luboń, and 30\% in Głogów. At the Kórnik site, several ECM fungal taxa occurred with relative abundance less than $1 \%$ with no subdominant species. At the Luboń site, subdominant mycorrhizas (27\%) were formed by $P$. finlandia. The subdominant ECM fungal species at the Głogów site were taxa from the Atheliaceae family (designated as Atheliaceae 1 and 2) and Pyrenomycetaceae. Together, two species from Atheliaceae family, which formed mycorrhizas with abundant extramatrical mycelium and rhizomorphs, comprised up to $32 \%$ of the ECM fungal community (Fig. 1). The Shannon-Wiener and Simpson diversity indices were substantially higher for Lubon than for the Kórnik and Glogów sites. The species dominance index was significantly influenced by site, and was highest in Głogów. The evenness coefficient did not differ significantly between tested sites (Table 3 ).

Fig. 1 Mean relative abundance of mycorrhizal fungal taxa associated with Scots pine at three study sites

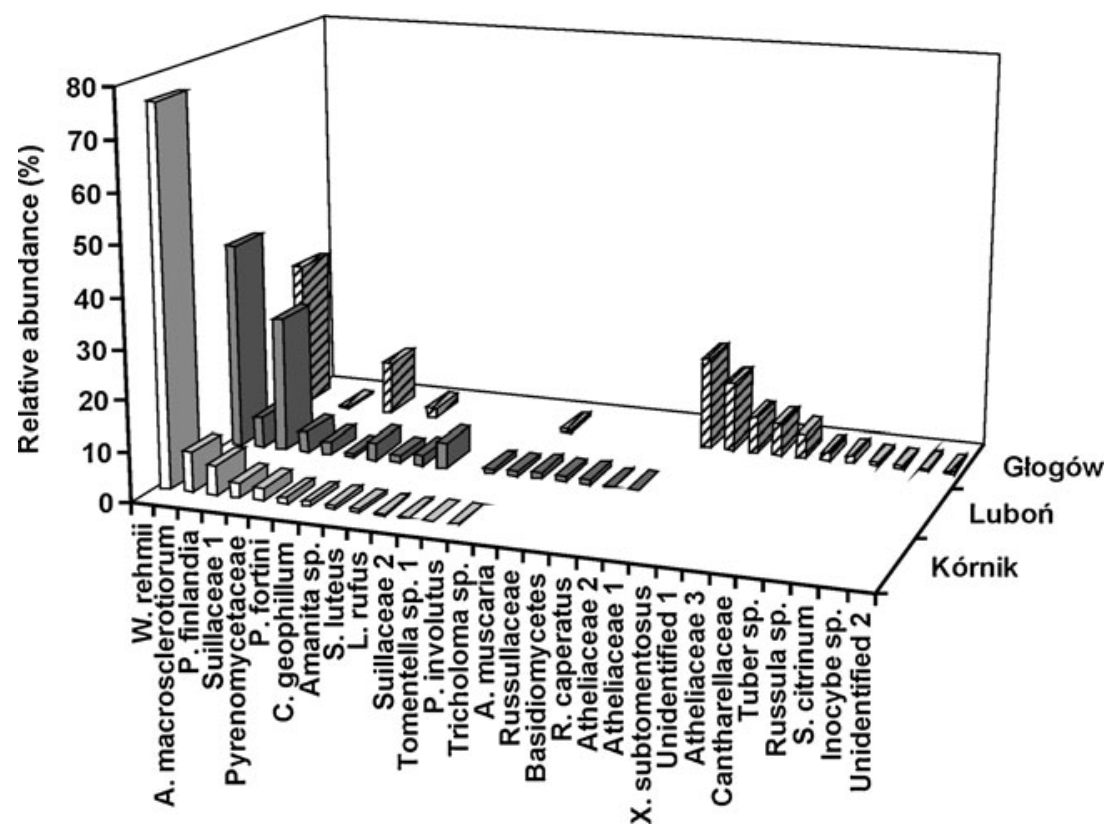




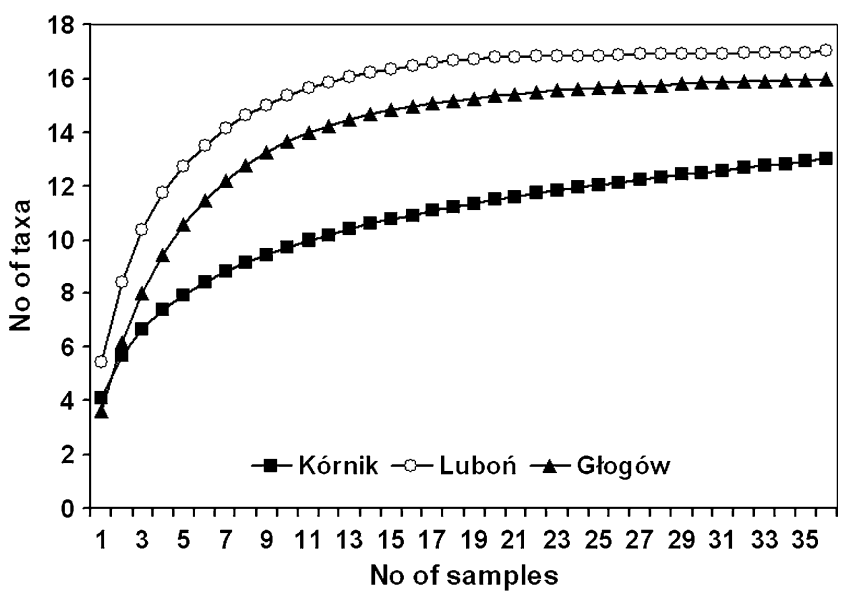

Fig. 2 The observed species accumulation curves for mycorrhizal fungal taxa associated with Scots pine at three study sites

The NMDS ordinations of the mycorrhizal communities demonstrated partial separation based on different Scots pine sites (Fig. 3, stress value 0.19). The most sample points for the Głogów site were separated from sample points for Kórnik and Głogów. The Kórnik and Luboń sites in the NMDS diagram are scattered and not well defined. Despite the partial overlap in the NMDS, ANOSIM revealed a significant difference between tested sites (global $R=0.52, P$ $<0.0001$, permutation $=10,000)$ and for all pairwise sites (Kórnik-Luboń, $R=0.31$; Kórnik-Głogów, $R=0.50$; LubońGłogów, $R=0.55 ; P<0.0001$ for all pairwise comparisons).

Functional diversity of ECM fungal communities was measured by subclassifying morphotypes into exploration types. Significant differences between the three sites were

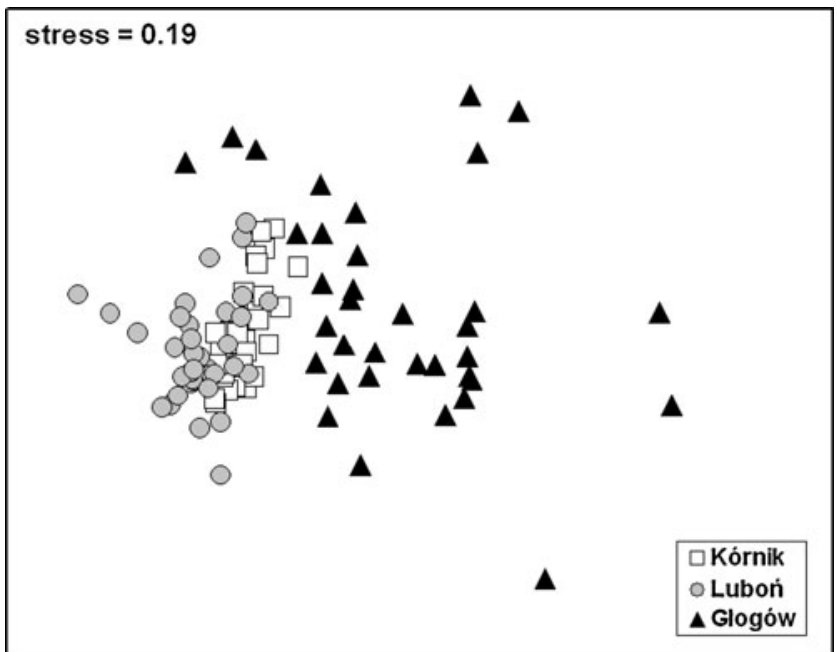

Fig. 3 Two-dimensional nonmetric scaling ordination plot of communities of ectomycorrhizas, based on Bray-Curtis coefficient. Each point is a representation of composition of ectomycorrhizas in individual soil sample observed with respect to relative abundance of contact $(p=0.0002)$, short $(p=0.002)$, medium fringe $(p=0.0001)$ and long exploration type $(p=0.03)$. The ECM community in Kórnik (control) was clearly dominated by fungi of the contact exploration type (76\%). At the Lubon site (near the chemical plant), contact and short distance exploration types were observed in highest abundance $(47 \%$ and $41 \%$, respectively). The site in Głogów (near the Copper Smelter), was characterized by high abundance of the medium fringe exploration type (37\%; Fig. 4).

The outcome of the CCA is given as a biplot containing environmental data (soil $\mathrm{pH}$ and nutrient concentrations) and exploration types (Fig. 5). The first two axes of the CCA, with eigenvalues of 0.292 and 0.065 , explained $39.8 \%$ of the species variance and $87 \%$ of the speciesenvironmental relationship (and most of this, $71.1 \%$, is contributed by the first, horizontal axis). A Monte Carlo permutation test (499 permutations) demonstrated that the relationship between the exploration types and the first canonical axis was statistically significant $(P=0.002)$. The CCA biplot demonstrated that some exploration types are correlated with environmental conditions. The relative abundance of medium fringe type was correlated with the soil $\mathrm{pH}$ and $\mathrm{N}_{-} \mathrm{NH}_{4}, \mathrm{~K}, \mathrm{Ca}, \mathrm{Mg}, \mathrm{Cd}, \mathrm{Cu}, \mathrm{Pb}, \mathrm{Zn}$, and $\mathrm{Fe}$ concentrations, while contact exploration type correlated with $\mathrm{N}_{-} \mathrm{NO}_{3}, \mathrm{Mn}$, and $\mathrm{P}$ concentrations. However, forward selection of the environmental variables showed that only $\mathrm{N}-\mathrm{NH}_{4}, \mathrm{~N}-\mathrm{NO}_{3}, \mathrm{Mn}, \mathrm{P}, \mathrm{Cd}, \mathrm{Cu}, \mathrm{Pb}$, and $\mathrm{Zn}$ contributed significantly to variance in the mycorrhizal community.

\section{Discussion}

In the present study, we determined the distribution of ECM fungi on three Scots pine sites differing in ecological

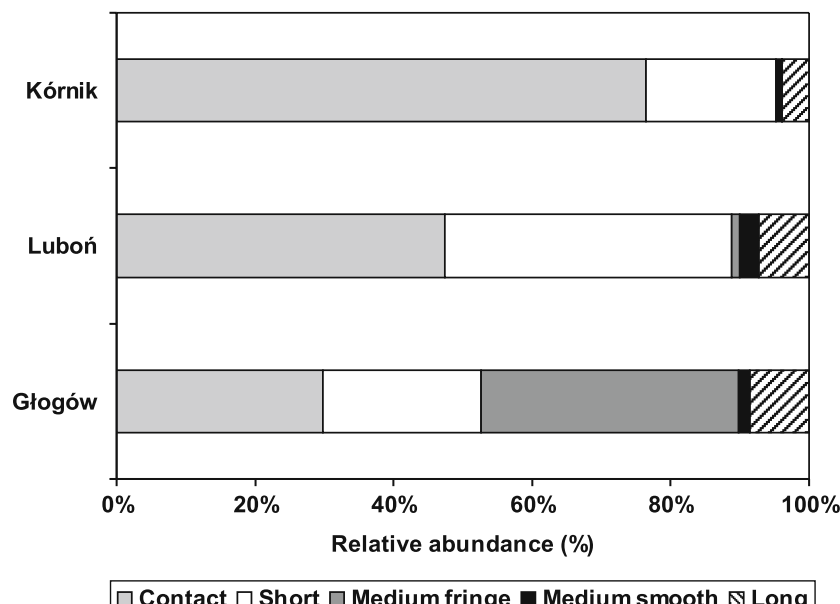

Fig. 4 Mean relative abundance of taxa with different exploration types associated with Scots pine at three study sites 


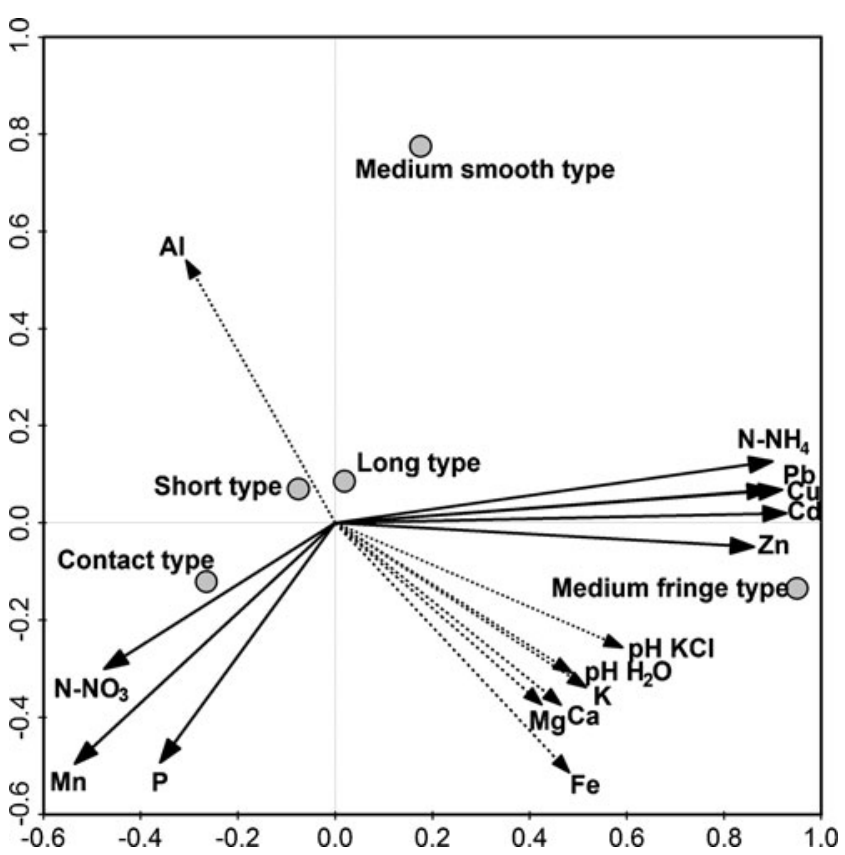

Fig. 5 Canonical correspondence analysis diagram of soil factors and mycorrhizal exploration types. Exploration types are represented by closed, gray circles. Environmental factors used to constrain ordination axes are represented by arrows. Factors with a significant effect are shown in bold (Monte Carlo permutation test, $P<0.05$ )

condition represented by history of the site, stand density and soil chemistry ( $\mathrm{pH}$, toxic metal content, etc.). Plant material, namely Scots pine trees were of this same age (20 years old) and originated from one single provenance region. By identifying sporocarps and mycorrhizas, we detected a total of 54 taxa of ECM fungi. Twenty-eight, 30, and 23 species were observed at the Kórnik (control), Lubon (near the chemical plant), and Głogów (near the Copper Smelter) sites, respectively (Fig. 6). The observed richness was within the wide range reported at sites in other Scots pine forests (e.g., Jonsson et al. 1999; Münzenberger et al. 2004; Urban et al. 2008). The sporocarp survey weakly reflected the analysis of ECM tips in terms of species composition, and largely supplemented the belowground view. Only two, four, and three ECM species were recorded as both sporocarp and mycorrhizas at Kórnik, Luboń, and Głogów, respectively (Fig. 6). Such discrepancies are in line with previous findings in which above- and belowground ECM communities were compared (e.g., Gardes and Bruns 1996; Jonsson et al. 2000; Peter et al. 2001), and confirm the importance of sampling both sporocarps and ectomycorrhizas to achieve an accurate estimate of the ECM community in forest ecosystems. This was particularly obvious in Kórnik (control site) where participation of ECM species producing sporocarps amounted to only $0.73 \%$ of the relative ECM abundance of the belowground community. Moreover, at Kórnik, we found that one species, W. rehmi, made up $76 \%$ of the belowground ECM community. Wilcoxina spp. are common in early successional or disturbed, often burned habitats and in soils with high organic matter or amended with peat (Egger et al. 1991; Grogan et al. 2000; Nara et al. 2003; Rudawska et al. 2006). As our control site was established after clear-cutting a poplar, deciduous forest, the inocula of ECM fungi in the soil should be different from those typical for coniferous trees. This may partly explain the observed very high abundance of $W$. rhemii considered as opportunistic species with poor competing abilities, flourishing only in the absence of the diverse or compatible fungal inoculum in the field (Cline et al. 2005). We cannot rule out the possibility that stand density also contribute to the high abundance of $W$. rehmii at control site in Kórnik. Further investigations about potential effects of stand density on belowground ECM community responses should be included in future studies but speculation about this problem is beyond the scope of this paper and is reserved for a forthcoming publication.

Because ECM sporocarps are connected with forest trees via the extrametrical mycelium and mycorrhizas, their production is tightly coupled to current assimilate supply (Kuikka et al. 2003). We presume that lower biomass allocation and thus restricted availability of soluble carbohydrates by the root system of pines grown in higher stand density (Kórnik) is reflected in very low sporocarp production during all 3 years when inventories were conducted. The site in Lubon (near the chemical plant) was characterized by an exceptionally high abundance of sporocarps $(2,223$ in 3 years). This phenomenon had already been observed in our previous studies (Rudawska et al. 1995) and to the certain extent may depend on stand density. Stimulating effect on mushroom yields was observed after reduction of stand density in $P$. sylvestris and Pinus nigra stands (Palahi et al. 2009). Mild stress originating from the chemical plant in Lubon could also

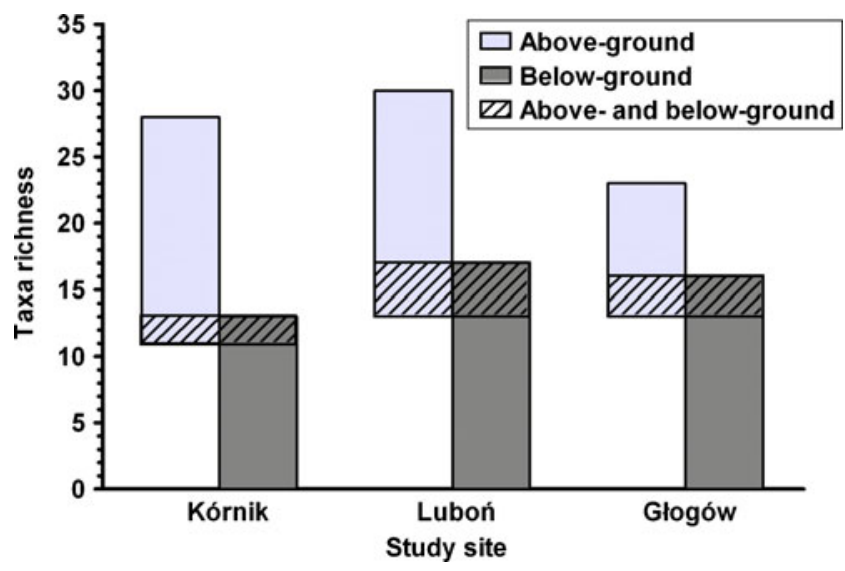

Fig. 6 Above- and belowground ectomycorrhizal species richness at the three tested Scots pine sites 
operate as potential signals involved in enhancing sporocarp production. The stimulating effect of pollution on the sporocarp production of some ECM species was sometimes reported (Rühling et al. 1984; Rühling and Söderström 1990). History of the site in Lubon which before establishing of the experimental plot was covered by scattered Scots pines and thus presumably rich in fungal propagules best suited to colonize Scots pine may also account for aboveand belowground ECM community of this site. However, with stress increasing (as in heavy metal-influenced site in Głogów near the Copper Smelter), both the lower number of fruiting species and the lower number of sporocarps has been observed, compared with slightly polluted site near the Chemical Plant in Lubon (Table 2 and Fig. 6). This is consistent with early observations about the negative effects of heavy metals on the sporocarp production and species richness of ECM fungi (Rühling and Söderström 1990; Tarvainen et al. 2003).

In comparison with the aboveground view, the belowground ECM community of Scots pine was structured differently due to the conditions of the tested sites. The total number of mycorrhizal tips per $1 \mathrm{~g}$ of root dry weight did not differ between Kórnik and Luboń, but was significantly lower at Głogów. Fine roots, which form the main interface between the tree and the soil solution has often been reported to suffer from high concentration of heavy metals in the soil (Colpaert and Van Assche 1993; Helmisaari et al. 1999).

The composition across morphotypes demonstrated lower species richness at Kórnik, compared with the other two sites $(13,17$, and 16 species, respectively). However, the first-order jackknife estimator of ECM richness on this site was 15.92. Hence, the observed number of ECM taxa was $82 \%$ of the estimated richness and practically come close to the level in the two other sites. Only five fungal species of belowground ECM community were shared between tested sites ( $W$. rehmii, P. finlandia, Pyrenomycetaceae type, Cenococum geophilum, and $P$. involutus). All these species belonged to ECM fungi ubiquitous in natural forests. Despite lower number of mycorrhizas observed at site near the Copper Smelter in Głogów, the belowground ECM species richness was close to the site near the chemical plant and higher than at the control site (Kórnik). This finding is in accordance with the data on European aspen growing on a heavy metal contaminated site (Krpata et al. 2008) but in contrast with a previous results from polluted sites, which have reported lower rates of mycorrhizal colonization, fewer fungal propagules, and lower species richness of ECM fungi (e.g., Hartley et al. 1997; Markkola et al. 2002). Instead, at site near the Copper Smelter (Głogów), a significant shift in species composition was observed. Similar shift in ECM species composition in metal contaminated soils has been mentioned in the literature (Hartley et al. 1999; Markkola et al. 2002). At the site situated near the Copper Smelter, effect of postagricultural history of the site on structuring ECM community after the 20 years since establishing of the experimental plot seems to be less important than effect of the toxic metals. ECM diversity increased with time since disturbance and at the abandoned sites, ectomycorrhiza was reestablished 25-30 years after abandonment (Boerner et al. 1996).

Apart from W. rehmii, which dominated at all three sites, some species of the ECM belowground community of Scots pine revealed trends that preferentially occur in one or two of the three tested sites. High relative abundance (27\%) was found for P. finlandia at Lubon (near the chemical plant), which was characterized by low $\mathrm{pH}$ and high aluminum availability. An interesting finding of our study was ectomycorrhizal morphotype Pinirhiza sclerotia (at Kórnik and Luboń site) formed by Acephala macrosclerotiorum B. Münzenberger \& B. Bubner, a close relative of Phialocephala fortini. Recently, Münzenberger et al. (2009) identified and described this sclerotia-forming morphotype in the organic layer and the mineral soil layer in the P. sylvestris forest area. In our study sites in Kórnik and Luboń, A. macrosclerotiorum was present in abundance $8 \%$ and $6 \%$, respectively, but was not observed on the site contaminated by heavy metals.

Evaluation of the belowground community data (based on exploration types) using CCA demonstrated that the abundance of particular mycorrhizal exploration types is related to soil chemistry. It is clearly seen that the contact type represented mainly by Wilcoxina mycorrhizas, well adapted to the nutrient rich conditions (Rudawska et al. 2006; Leski et al. 2008), correlates with higher nutrient availability (Fig. 5). A very large proportion of mediumfringe exploration type belonging to Atheliaceae was found exclusively on the heavy metal-influenced site near the Copper Smelter in Głogów. It remains unknown what kind of ecological function is performed by this group of fungi. Atheliaceae morphotypes were characterized by a very abundant orange-brown emanating hyphae and ramifying hairy rhizomorphs. These features may be of importance as a filter preventing the entrance of toxic metals into the host plant cells via mycorrhizas (Leyval et al. 1997). It is likely that Atheliaceae are well adapted to stressful environmental conditions. Atheliaceae was recently found in a species assemblage of $P$. sylvestris grown in the serpentine study site (Urban et al. 2008). Additional research will be needed to determine whether the shift in the ECM community that was found in metal-contaminated soil reflects responses on the part of the host tree or an increase in the competitive ability of Atheliaceae fungi when the abundance of other ECM symbionts decreases. A site-specific belowground ECM community was confirmed at the Głogów site by NMDS and ANOSIM. Sample points from Głogów were 
most obviously separated from those of Kórnik and Luboń on a multidimensional plot.

In conclusion, various patterns of ECM fungal communities could be distinguished by comparing above- and belowground ECM associations of Scots pine trees grown in monocultures at three different sites. It is impossible however to separate the precise reasons of the distribution of ECM fungi because of the number of covarying site properties which may influence ECM communities. Continued research on the biodiversity of ECM fungi in field sites along an environmental gradient would greatly improve our understanding of the effects of ecological conditions on the functional diversity of mycorrhizal fungi.

Open Access This article is distributed under the terms of the Creative Commons Attribution Noncommercial License which permits any noncommercial use, distribution, and reproduction in any medium, provided the original author(s) and source are credited.

\section{References}

Agerer R (1987-2008) Colour Atlas of Ectomycorrhizae. Einhorn, Schwäbisch-Gmünd

Agerer R (2001) Exploration types of ectomycorrhizae. Mycorrhiza 11:107-114

Aučina A, Rudawska M, Leski T, Skridaila A, Riepšas E, Iwański M (2007) Growth and mycorrhizal community structure of Pinus sylvestris seedlings following the addition of forest litter. Appl Environ Microbiol 73:4867-4873

Boerner REJ, DeMars B, Leicht PN (1996) Spatial patterns of mycorrhizal infectiveness of soils along a successional chronosequence. Mycorrhiza 6:79-90

Cairney JWG, Meharg AA (1999) Influences of anhropogenic pollution on mycorrhizal fungal communities. Environ Pollut 106:169-182

Cline ET, Ammirati JF, Edmonds RL (2005) Does proximity to mature trees influence ectomycorrhizal fungus communities of Douglas-fir seedlings? New Phytol 166:993-1009

Colpaert JV, Van Assche JA (1993) The effects of cadmium on ectomycorrhizal Pinus sylvestris. New Phytol 123:325-333

Dahlberg A (2001) Community ecology of ectomycorrhizal fungi: an advancing interdisciplinary field. New Phytol 150:555-562

Dahlberg A, Jonsson L, Nylund JE (1997) Species diversity and distribution of biomass above- and below-ground among ectomycorrhizal fungi in an old-growth Norway spruce forest in South Sweden. Can J Bot 75:1323-1335

Egger KN, Danielson RM, Fortin JA (1991) Taxonomy and population structure of E-strain mycorrhizal fungi inferred from ribosomal and mitochondrial DNA polymorphisms. Mycol Res 95:866-872

Erland S, Taylor AFS (2002) Diversity of ecto-mycorrhizal fungal communities in relation to the abiotic environment. In: van der Heijden MGA, Sanders I (eds) Mycorrhizal ecology. Ecological studies. Springer, Berlin, pp 163-200

Finlay RD, Lindahl BD, Taylor AFS (2008) Responses of mycorrhizal fungi to stress. In: Avery SV, Stratford M, Van West P (eds) Stress in yeasts and filamentous fungi. Elsevier, Academic Press, pp 201-220
Gardes M, Bruns TD (1996) Community structure of ectomycorrhizal fungi in a Pinus muricata forest: above- and below-ground views. Can J Bot 74:1572-1583

Grogan P, Baar J, Bruns TD (2000) Below-ground ectomycorrhizal community structure in a recently burned bishop pine forest. $\mathrm{J}$ Ecol 88:1051-1062

Grossnickle SC, Reid CPP (1983) Ectomycorrhiza formation and root development patterns of conifer seedlings on a high-elevation mine site. Can J For Res 13:1145-1158

Hartley JW, Cairney G, Meharg AA (1997) Do ectomycorrhizal fungi exhibit adaptive tolerance to potentially toxic metals in the environment? Plant Soil 189:303-319

Hartley J, Cairney JWG, Freestone P, Woods C, Meharg AA (1999) The effects of multiple metal contamination on ectomycorrhizal Scots pine (Pinus sylvestris) seedlings. Environ Pollut 106:413-424

Haselwandter K, Bowen GD (1996) Mycorrhizal relations in trees for agroforestry and land rehabilitation. For Ecol Manag 81:1-17

Helmisaari HS, Makkonen K, Olsson M, Viksna A, Mälkönen E (1999) Fine-root growth, mortality and heavy metal concentrations in limed and fertilized Pinus silvestris (L.) stands in the vicinity of a Cu-Ni smelter in SE Finland. Plant Soil 209:193200

Henrion B, Chevalier G, Martin F (1994) Typing truffles species by PCR amplification of the ribosomal DNA spacers. Mycol Res 98:37-43

Hintikka V (1988) On the macromycete flora in oligotrophic pine forests of different ages in South Finland. Acta Bot Fenn 17:855858

Horton TR, Bruns TD (2001) The molecular revolution in ectomycorrhizal ecology: peeking into the black box. Mol Ecol 10:18551871

Jones MD, Durall DM, Cairney JWG (2003) Ectomycorrhizal fungal communities in young forest stands regenerating after clearcut logging. New Phytol 157:399-422

Jonsson L, Dahlberg A, Nilsson MC, Zackrisson O, Kårén O (1999) Ectomycorrhizal fungal communities in late-successional Swedish boreal forests, and their composition following wildfire. Mol Ecol $8: 205-215$

Jonsson L, Dahlberg A, Brandrud TE (2000) Spatiotemporal distribution of an ectomycorrhizal community in an oligotrophic Swedish Picea abies forest subjected to experimental N addition, above- and below-ground views. For Ecol Manage 132:143-156

Kabata-Pendias A, Mukherjee AB (2007) Trace elements from soil to human. Springer, Berlin

Kåren O, Hogberg N, Dahlberg A, Jonsson L, Nylund JE (1997) Interand intraspecific variation in the ITS region of rDNA of ectomycorrhizal fungi in Fennoscandia as detected by endonuclease analysis. New Phytol 136:313-325

Karolewski P, Giertych MJ (1995) Changes in the level of phenols during needle development in Scots pine populations in a control and polluted environment. Eur J For Path 25:297-305

Kernaghan G (2005) Mycorrhizal diversity: cause and effect? Pedobiologia 49:511-520

Krpata D, Peintner U, Langer I, Fitz WJ, Schweiger P (2008) Ectomycorrhizal communities associated with Populus tremula growing on a heavy metal contaminated site. Mycol Res 112:1069-1079

Kuikka K, Härmä E, Markkola A, Rautio P, Roitto M, Saikkonen K, Ahonen-Jonnarth U, Finlay R, Tuomi J (2003) Severe defoliation of Scots pine reduces reproductive investment by ectomycorrhizal symbionts. Ecology 84:2051-2061

Leski T, Rudawska M, Aučina A (2008) The ectomycorrhizal status of European larch (Larix decidua Mill.) seedlings from bareroot forest nurseries. For Ecol Manag 256:2136-2144 
Leski T, Pietras M, Rudawska M (2010) Ectomycorrhizal fungal communities of pedunculate and sessile oak seedlings from bareroot forest nurseries. Mycorrhiza 20:179-190

Leyval C, Turnau K, Haselwandter K (1997) Effect of heavy metal pollution on mycorrhizal colonization and function: physiological, ecological and applied aspects. Mycorrhiza 7:139-153

Markkola AM, Ahonen JU, Roitto M, Strommer R, Hyvarinen M (2002) Shift in ectomycorrhizal community composition in Scots pine (Pinus sylvestris L.) seedling roots as a response to nickel deposition and removal of lichen cover. Environ Pollut 120:797-803

Münzenberger B, Golldack J, Ullrich A, Schmincke B, Huttl RF (2004) Abundance, diversity, and vitality of mycorrhizae of Scots pine (Pinus sylvestris L.) in lignite recultivation sites. Mycorrhiza 14:193-202

Münzenberger B, Bubner B, Wöllecke J, Sieber TN, Bauer R, Fladung M, Hüttl RF (2009) The ectomycorrhizal morphotype Pinirhiza sclerotia is formed by Acephala macrosclerotiorum sp. nov., a close relative of Phialocephala fortinii. Mycorrhiza 19:481-492

Nara K, Nakaya H, Wu BY, Zhou ZH, Hogetsu T (2003) Underground primary succession of ectomycorrhizal fungi in a volcanic desert on Mount Fuji. New Phytol 159:743-756

Oleksyn J (1988) Height growth of different European Scots pine (Pinus sylvestris L.) provenances in a heavily polluted and a control environment. Environ Pollut 55:289-299

Palahi M, Pukkala T, Bonet JA, Colinas C, Fischer CR, Martínez de Aragón JR (2009) Effect of the inclusion of mushroom values on the optimal management of even-aged pine stands of Catalonia. For Sci 55:503-511
Peter M, Ayer F, Egli S (2001) Nitrogen addition in a Norway spruce stand altered macromycete sporocarp production and below-ground ectomycorrhizal species composition. New Phytol 149:311-325

Rudawska M, Kieliszewska-Rokicka B, Leski T, Oleksyn J (1995) Mycorrhizal studies of a Scots pine plantation affected by pollution from a phosphate fertilizer plant. Water Air Soil Pollut 85:1281-1286

Rudawska M, Leski T, Trocha LK, Gornowicz R (2006) Ectomycorrhizal status spruce seedlings from bare-root forest nurseries. For Ecol Manage 236:375-384

Rühling A, Söderström B (1990) Changes in fruitbodies production of mycorrhizal and litter decomposing macromycetes in heavy metal polluted coniferous forest in North Sweden. Water Air Soil Pollut 49:375-387

Rühling A, Bååth E, Nordgren A, Söderström B (1984) Fungi in metal-contaminated soil near the Gusum brass mill, Sweden. Ambio 13:34-36

Simard SW (2009) Response diversity of mycorrhizas in forest succession following disturbance. In: Azcon-Aguilar C, Barea JM, Gianinazzi S, Gianinazzi-Pearson V (eds) Mycorrhizas: functional processes and ecological impacts. Springer, Heidelberg, pp 187-206

Smith SE, Read DJ (1997) Mycorrhizal symbiosis, 2nd edn. Academic, London

Tarvainen O, Markkola AM, Strommer R (2003) Diversity of macrofungi and plants in Scots pine forests along an urban pollution gradient. Basic Appl Ecol 4:547-556

Urban A, Puschenreiter M, Strauss J, Gorfer M (2008) Diversity and structure of ectomycorrhizal and co-associated fungal communities in a serpentine soil. Mycorrhiza 18:339-354 